\title{
PARALAXE E "MARCAÇÃO POR TERRA": TÉCNICAS DE NAVEGAÇÃO ENTRE JANGADEIROS NA PARAÍBA E RIO GRANDE DO NORTE (BRASIL)
}

Gabriel Coutinho Barbosa Rafael Devos

Um tema relativamente pouco estudado em antropologia é aquele das técnicas de navegação. Os estudos mais conhecidos sobre o tema referem-se sobretudo à paisagem etnográfica da Micronésia e Polinésia, notabilizada pela habilidade dos nativos em velejar longas distâncias sem a ajuda de instrumentos magnéticos, mecânicos ou eletrônicos, em uma vastidão de mar pontilhada de pequenas porções de terra. No que diz respeito à literatura sobre as populações costeiras no Brasil, o assunto tem sido timidamente abordado em comparação com temas como técnicas de pesca, organização social e/ou do trabalho, impactos do mercado e da industrialização, conflitos socioambientais.

Este artigo apresenta uma análise das técnicas de navegação, pesca e habilidades perceptuais desenvolvidas por pescadores em jangadas e outras embarcações no litoral norte paraibano e sul potiguar, entre os municípios de Baía da Traição e Baía Formosa. ${ }^{1}$ Tratamos aqui da navegação e da localização de pesqueiros à luz do dia e mantendo a costa à vista, ao que parece, no interior de um raio de pouco mais que 12 milhas náuticas, cerca de 25 quilômetros da costa. É a chamada "marcação por terra" ou "marcação por caminho e assento". Na navegação em alto-mar e noturna, esta técnica é combinada com outras, como os usos de linha de corso (ver nota 06), "saçanga" e estrelas.

Surgidas em meados do século XX, as jangadas de tábuas substituíram as jangadas de pau, também conhecidas como jangadas de piúba (Cascudo 2002 [1957]). De construção e manutenção relativamente fácil e barata, elas são feitas com tábuas pregadas em cavername, formando um pequeno porão, geralmente preenchido com placas de isopor, que serve tanto para flutuação como para a conservação do pescado. Outras invenções sofisticadas que conferem enorme eficácia à jangada são: bolina retrátil em um casco chato e resistente, capaz de transpor os arrecifes na costa, ideal para 
partidas e chegadas na praia, e que não afunda em caso de adernagem; um mastro feito de segmentos de madeira amarrados, que verga otimizando a navegação contra o vento; uma vela principal que se pode enrolar com facilidade tanto para ajuste à intensidade do vento como para a retirada do mastro quando se quer manter a embarcação parada na praia ou sobre pesqueiros no mar; a "carlinga", que é uma tábua sob o "banco da vela" no convés, dotada de furos que permitem o ajuste fino da angulação do mastro conforme a direção do vento.

Figura 1: A jangada de tábuas e seus componentes, a partir de desenhos de Araújo (1990)

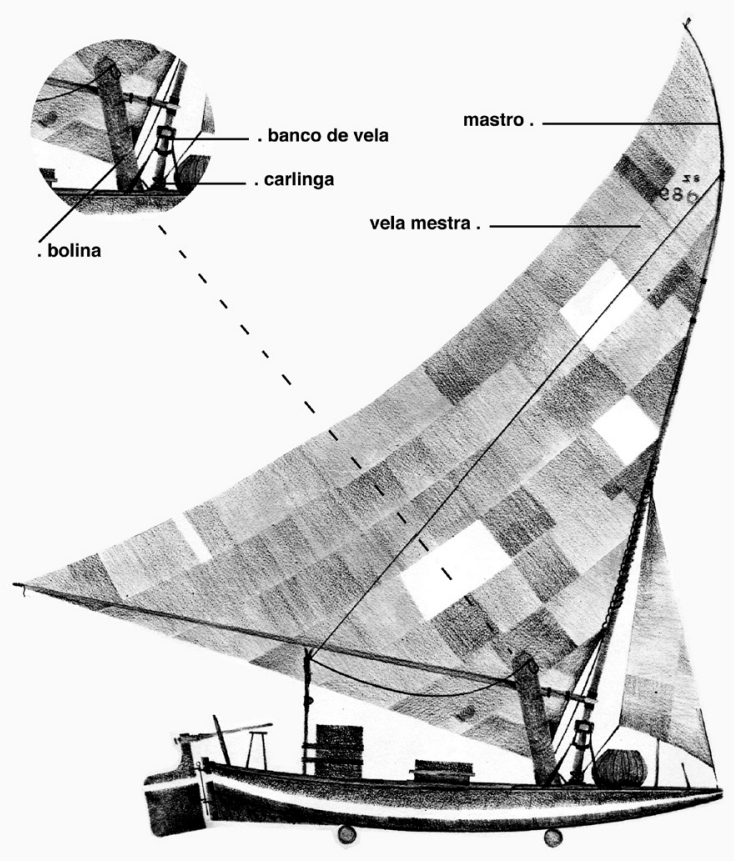

Para a análise aqui realizada, baseamo-nos em um balanço da literatura sobre os temas em questão e, sobretudo, em etnografia. Do tema mais amplo da navegação, tratamos dos dois grandes modelos teóricos existentes, aquele dos "mapas mentais" e outro que chamamos de abordagem ecológica. Destacamos os pressupostos destes, seu rendimento para a compreensão das práticas aqui analisadas, além de suas relações com teorias cognitivistas e pós-cognitivistas sobre a percepção. Quando oportuno, comparamos a "marcação por terra" com outras técnicas de navegação. Valemo-nos de informações e análises disponíveis na literatura sobre pesca no litoral nor- 
deste brasileiro, mas principalmente de dados etnográficos produzidos ao longo de quatro viagens de campo aos municípios de Baía da Traição e Baía Formosa, ${ }^{2}$ breves em 2012, 2014 e 2015, e por um período mais extenso em 2016. Além de conversar com pescadores na praia enquanto estes faziam reparos e preparativos em suas jangadas, tivemos o privilégio de acompanhar alguns deles a alguns pesqueiros na costa de Baía da Traição. Essas experiências permitiram compreender alguns dos fundamentos da navegação por "marcação por terra" de que trataremos a seguir.

\section{Segredo de pedras}

Uma das habilidades mais notáveis de jangadeiros e demais pescadores na região é a localização de pesqueiros já conhecidos e por eles visitados com frequência. Chamados de pedras, esses pesqueiros são pedras propriamente ditas, arrecifes de arenito, coral ou mesmo formações artificiais, como naufrágios e pesqueiros botados (pedaços de paus, pedras e outros materiais jogados ao mar), que se encontram submersos, sem qualquer sinalização, como boia ou bandeira. Conforme sua localização, profundidade, tipo de fundo, a época do ano e a maré, as pedras abrigam diferentes espécies de peixes e crustáceos. Os pescadores classificam esses pesqueiros de acordo com a faixa de profundidade em que se encontram. Segundo Oliveira, experiente pescador na região, os tassis encontram-se entre 5 e 9 braças de profundidade (aproximadamente, 9 e 16 metros); as corubas, entre 10 e 13 braças (18 e 23 metros); o raso seco, a 15 braças (27 metros); os rasos, entre 21 e 27 braças (certa de 37 e 48 metros); a parede seca, entre 31 e 37 braças (55 e 66 metros); a parede funda, de 55 a 90 braças (de 100 a 160 metros) e os altos, de 100 a 160 braças (180 e 290 metros). ${ }^{3}$ No mais, cada pesqueiro recebe um nome que costuma remeter ao pescador responsável pela sua descoberta, a eventos associados e/ou características da paisagem. "Raso do Assobio", "Tassi da Barreta", "Tassi do Elias", "Velho Zuza", "Ponta de Coqueiro" e "Guaju de Baixo" são alguns dos pesqueiros na costa de Baía da Traição.

A localização da maioria dos pesqueiros constitui segredo compartilhado por poucos, sendo indicada geralmente por um mestre a seu(s) filho(s) e/ou alguns companheiros de pesca, membros de sua tripulação. O segredo busca garantir o privilégio de exploração exclusiva dos recursos, fundamentando certa divisão dinâmica do mar em áreas de pesca transitórias. Como veremos, a técnica de marcação por terra, empregada para se chegar aos pesqueiros conhecidos, favorece a manutenção do segredo sobre a sua localização. 
À medida que algumas dessas pedras são descobertas por muitos pescadores e têm seus recursos exauridos, antigos pesqueiros voltam a ser visitados e novos tendem a ser descobertos. O conhecimento sobre a localização das pedras, as habilidades náuticas e haliêuticas, assim como a autoridade sobre os tripulantes da embarcação conferem renome, ou "mestrança", a alguns pescadores (Maldonado 1993:108; Diegues 2001:393; Ramalho 2007:138139; Kottak 1966:218).

Articulando percepção afinada e conhecimento sofisticado do ambiente, os pescadores são capazes de reencontrar essas pedras sem a ajuda de qualquer equipamento magnético, eletrônico ou mecânico. Para tanto, valem-se da técnica de marcação por terra. Examinamos aqui esta técnica, destacando os pressupostos em que se baseia e, principalmente, seu modo de operação. Ao fazê-lo, aprofundamos as descrições já disponíveis na literatura (Cascudo 2002 [1957]; Kottak 1966; Forman 1970; Maldonado 1993; Diegues 2001; Ramalho 2007), atentando para aspectos importantes ainda não considerados.

\section{A marcação por terra e a conta d'água}

Figura 2: Fazendo a "marcação por terra"

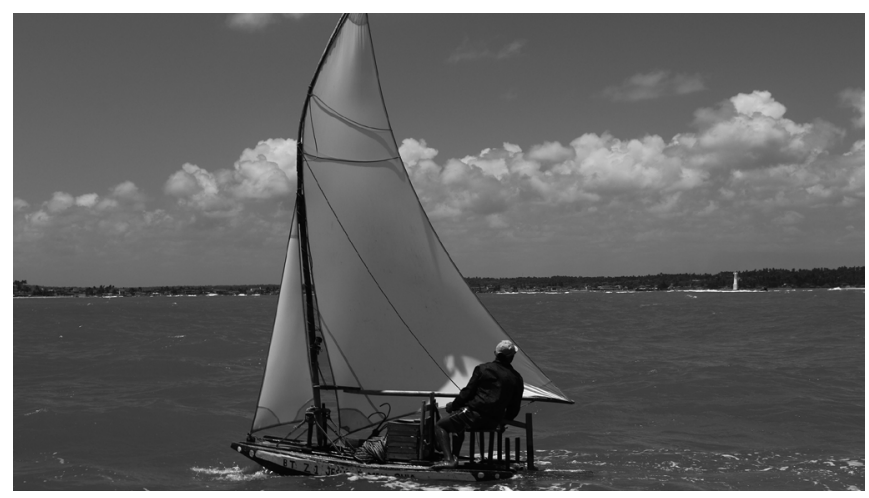

(foto de Rafael Devos)

A marcação por terra de um pesqueiro resulta da combinação de dois alinhamentos formados por pares de marcos terrestres distintos. Cada um dos alinhamentos, chamados de caminho e assento, respectivamente, constitui uma reta traçada a partir de um par de marcos na costa previamente determinados. Os marcos podem ser uma árvore, ponta de morro ou duna, farol, antena de rádio, TV ou celular, o telhado de uma casa, enfim, qualquer coisa discernível na paisagem à distância a partir do mar. ${ }^{4}$ Ao sair para 
um pesqueiro, o jangadeiro volta sua atenção para dois marcos terrestres iniciais. Conforme a embarcação se afasta da costa em uma dada direção, o jangadeiro vê esses dois marcos terrestres deslocarem-se devido ao fenômeno de paralaxe de movimento relativo, isto é, a percepção de deslocamento do objeto observado conforme o movimento do observador. Situados a diferentes distâncias deste, os marcos deslocam-se em relação à embarcação e também um em relação ao outro em direções e velocidades angulares distintas.

O marco mais próximo move-se em sentido contrário à embarcação e a uma maior velocidade angular do que o marco mais distante, que segue na mesma direção da embarcação. ${ }^{5}$ Quando o marco terrestre mais próximo interpõe-se entre a embarcação e o marco mais distante, escondendo parcialmente este último, a embarcação e os dois marcos terrestres encontram-se devidamente alinhados. Os jangadeiros com os quais conversamos dizem que os marcos terrestres "correm até emparelhar". São "terra corrente" ou "terra que gira", nos termos de Oliveira e Birino, pescadores na região (24/11/2015). Câmara Cascudo menciona a expressão "encher caminho" (2002 [1957]:28) e Diegues fala em "sinais de terra [...] que vão subindo, descendo e andando durante a navegação" (2001:391, grifos nossos), citando os jangadeiros dos municípios de Tibau do Sul e Galinhos, respectivamente.

Figura 3: Alinhamento por paralaxe de movimento relativo de farol com início de coqueiral
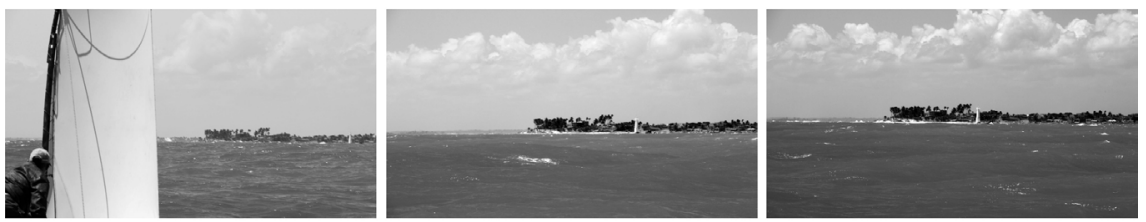

(fotos de Rafael Devos)

Ao se alinhar com o primeiro par de marcos terrestres, o navegador imagina o prolongamento da reta que os une, tomando-o como rumo a seguir. Esta reta traçada é o caminho do pesqueiro de destino. A partir daí, o navegador dirige sua atenção para outros dois marcos conhecidos na costa, que se deslocam à distância conforme a embarcação avança pelo caminho. O alinhamento deste segundo par de marcos com a embarcação forma uma nova reta, que é o assento. O pesqueiro procurado encontra-se submerso na posição em que é possível avistar simultaneamente os dois alinhamentos, caminho e assento. Cabe ao pescador, então, localizar com maior precisão a pedra no fundo do mar para fundear a embarcação. Para tanto, ele lança a poita ou âncora e recolhe as velas mestra e de estai, evitando que o vento 
afaste a jangada do setor, a área estimada pela marcação por terra. Em seguida, manobra a embarcação com cuidado, zingando, isto é, movendo o "remo de zinga" com o balanço de seu próprio corpo, ou simplesmente deixando a jangada ser levada pela correnteza e pelo vento.

Orientando-se pela cor da água, textura da superfície do mar e, sobretudo, por sondagem feita com a saçanga, um fio longo e resistente com um peso amarrado em uma das pontas, o pescador examina a profundidade, ou conta d'água, o relevo e a composição do fundo do mar, se de pedra ou areia. ${ }^{6}$ Ao encontrar a pedra, cabe ao pescador estimar a posição do pesqueiro. Este, como veremos adiante, mais do que a pedra em si, é a sua relação com as marés, correntes e o comportamento dos cardumes. Uma vez estimado, ele amarra firme o cabo da poita no tolete e lança as linhas de pesca. Oliveira, por exemplo, utilizou três alinhamentos para encontrar um pesqueiro. Um primeiro par de caminho e assento indicou o setor, local (e momento) para lançar a poita na água. Em seguida, com o cabo da poita em mãos, Oliveira deixou a embarcação ser levada pela corrente até que fosse avistado um terceiro alinhamento, indicando onde deixar a embarcação.

\section{Linhas sobre uma superfície}

Em um dos trabalhos mais instigantes sobre navegação, o antropólogo Edwin Hutchins afirma que todo sistema de navegação precisa lidar com três questões centrais, independente dos conceitos e das suposições culturalmente variáveis a que se encontra sempre atrelado e que costumam afetar as operações que realiza (voltaremos a este ponto mais adiante). ${ }^{7}$ São elas: Onde estou? De onde estou, como faço para chegar a um lugar específico? E, por fim, onde estarei se proceder, a partir de onde estou, a uma determinada velocidade e em uma dada direção por certo período de tempo? (Hutchins 1995:52, 54)

Ao recorrer a exemplos da náutica ocidental para ilustrar aspectos das operações realizadas para responder a tais questões, o autor reconhece reproduzir necessariamente suposições representacionais em que estes se baseiam (Hutchins 1995:50-51). Assim, de acordo com ele, toda localização de um ponto qualquer sobre uma superfície, como uma posição no mar, requer alguma combinação entre pelo menos duas delimitações (constraints) unidimensionais, chamadas na moderna náutica ocidental de "linhas de posição". Há dois tipos principais de "linhas de posição", definidos pela relação de uma posição conhecida com uma direção particular ou uma distância específica. No primeiro caso, sabe-se que a posição procurada 
(ponto B) encontra-se em uma dada direção da posição conhecida (ponto A), ou seja, em uma linha reta que se estende a partir do ponto A na direção determinada. No segundo, sabe-se que o ponto B repousa a certa distância do ponto A, isto é, em um círculo ou "arco de posição" que tem o ponto A como centro e um raio com a distância especificada. Em suma, uma "linha" ou "arco de posição" corresponde ao lugar geométrico de todas as posições que a embarcação ou o destino buscado, como um pesqueiro, pode ocupar em certo instante.

Figura 4: [a] "linha de posição" e [b] "arco de posição"

[a]

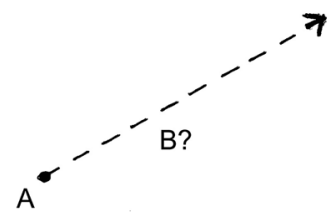

[b]

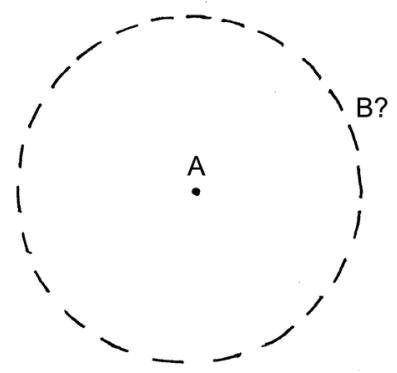

(ilustração: Bruno Aied Passos)

Para estabelecer uma posição, é necessário combinar duas ou mais "linhas" e/ou "arcos de posição". É justamente o que fazem os jangadeiros no caso da marcação, ao determinarem a posição do pesqueiro pela interseção das retas de caminho e assento, cada qual produzida pelo alinhamento da embarcação com um par distinto de marcos terrestres. Trata-se de uma combinação de "linhas de posição" bastante comum na navegação costeira e em águas restritas, que possui como vantagens a maior precisão e o fato de prescindir de qualquer instrumento, inclusive de carta náutica. As únicas condições para tanto são: a visibilidade dos marcos em certo destaque na paisagem - como dizem os jangadeiros, "terra limpa"; que o marco mais distante tenha altitude maior que o marco mais próximo e que o navegador se desloque na direção certa de modo a produzir o alinhamento. Por sua vez, uma terceira "linha" de caráter complementar é fornecida pela conta d'água que, ao seu modo, faz as vezes de "linha de posição isobatimétrica" na moderna náutica ocidental. Não se trata apenas de ir de um lugar a outro, em um deslocamento horizontal sobre a superfície do mar, mas de encontrar a pedra submersa. 
Figura 5: Localização de pesqueiro pela combinação de "linhas de posição": [A] "caminho", [B] "assento" e [C] "conta d'água"

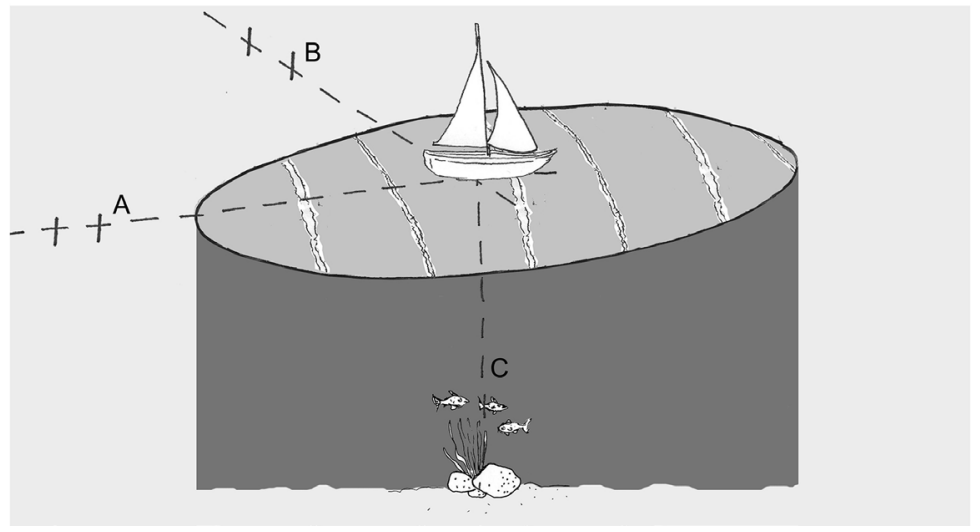

(ilustração: Bruno Aied Passos)

\section{Coordenadas em um mapa, caminhos no mundo}

Há inúmeros pesqueiros distribuídos pela costa entre Baía da Traição e Baía Formosa. Seria impossível e desnecessário contar e mapeá-los em razão do "segredo" sobre sua localização e do caráter transitório de muitos deles. Não dispondo sequer de uma estimativa, propomos para fins de reflexão imaginar apenas sete pontos no litoral de Baía da Traição - quantidade muito inferior à realidade - cada qual com seus respectivos caminhos e assentos. Pois bem, se todas essas retas de caminhos e assentos fossem projetadas simultaneamente sobre um mapa da região, teríamos uma figura recortada por linhas entrecruzadas, semelhantes a coordenadas geográficas, ainda que formando uma tessitura irregular em vez de um xadrez simétrico. Foi muito provavelmente com uma figura semelhante em mente que Câmara Cascudo se referiu a "formas empíricas da latitude e da longitude que se denominaram caminho e assento, o primeiro de norte a sul e o segundo de leste a oeste, enfim, navegação observada pela marcação de pontos fixos no litoral" (2002 [1957]:92, grifos nossos). 
Figura 6: Mapas com a projeção de sete marcações imaginárias no litoral de Baía da Traição (PB), com seus respectivos [a] caminhos e assentos e [b] coordenadas de latitude e longitude
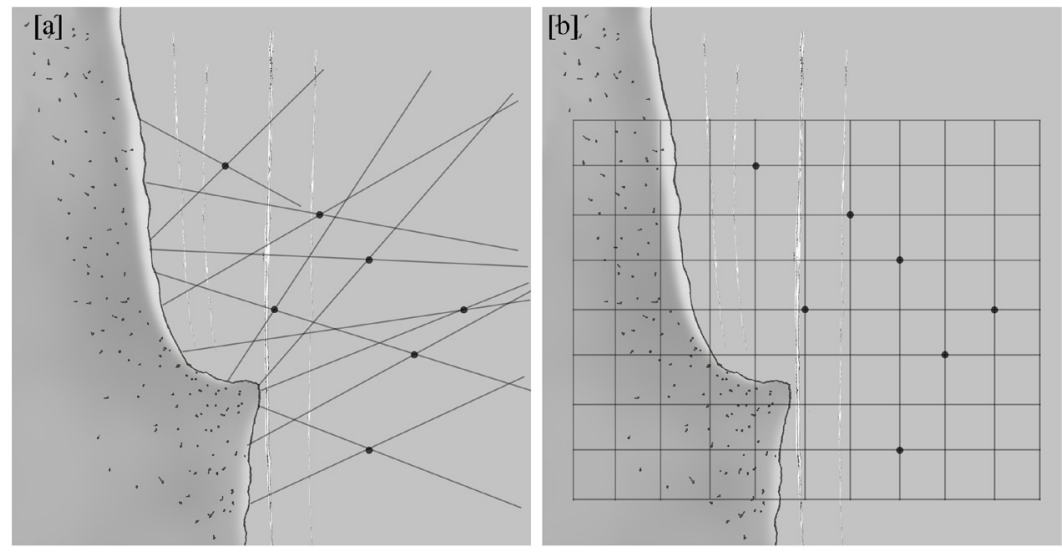

(ilustração: Bruno Aied Passos)

Chegamos assim a três ideias fortemente correlacionadas: de caminhos e assentos como coordenadas geográficas, da marcação como pautada na observação de "pontos fixos" e, por fim, da própria navegação como localização de pontos sobre uma superfície. Todas estas três ideias baseiam-se em uma concepção cartográfica moderna, materializada em mapas e cartas. Mapas são representações bidimensionais e em pequena escala que possuem certa analogia com as porções tridimensionais e mais amplas do mundo, representadas de modo a haver correspondência entre posições no mapa e no mundo. A perspectiva assumida e apresentada pelo mapa é a de um observador externo com vista aérea, pretensamente totalizante e objetiva, isto é, capaz de expor de maneira sinóptica e sincrônica um quadro com a disposição recíproca dos objetos na extensão representada, independente das perspectivas locais. O mundo é concebido e representado como um espaço exterior e absoluto, independente do observador e, mais importante, uma superfície imóvel, repleta de objetos fixos, sobre a qual se deslocam pessoas, animais e embarcações, entre outros (Gell 1985:278; Certeau 2001 [1990]:204-205; Hutchins 1995:62; Ingold 2000:242) ${ }^{8}$

Tal entendimento, porém, não corresponde à experiência dos jangadeiros, nem àquilo que afirmam. A perspectiva destes ao navegar, em vez de aérea, encontra-se embarcada, pouco acima do nível do mar, sujeita a oscilações conforme a ondulação. No mais, como dizem baseados nessa experiência, os marcos terrestres utilizados para fazer os alinhamentos, ao 
contrário de fixos, "correm", "giram", “enchem" e "andam". A diferença de pontos de vista em questão é aquela entre o observador que se debruça sobre um mapa e o participante que se encontra no ambiente. Enquanto o primeiro concebe o deslocamento da embarcação como o movimento exterior de um objeto sobre uma superfície imóvel, o participante embarcado experimenta o mesmo deslocamento como movimento de si e das próprias coisas em um ambiente dinâmico ao seu redor (Gell 1985:280-281; Hutchins 1995:62; Ingold 2000:241, 2011:96).

Figura 7: Perspectivas [a] cartográfica e [b] embarcada do alinhamento de embarcação e marcos terrestres
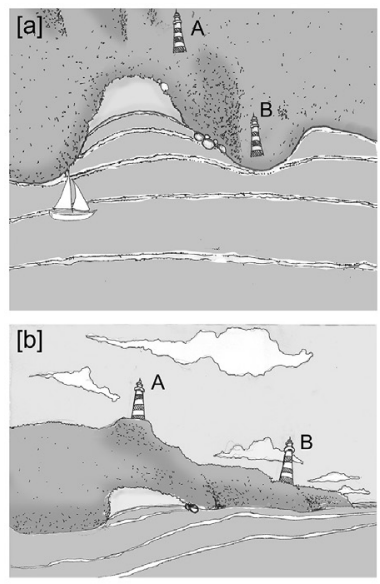
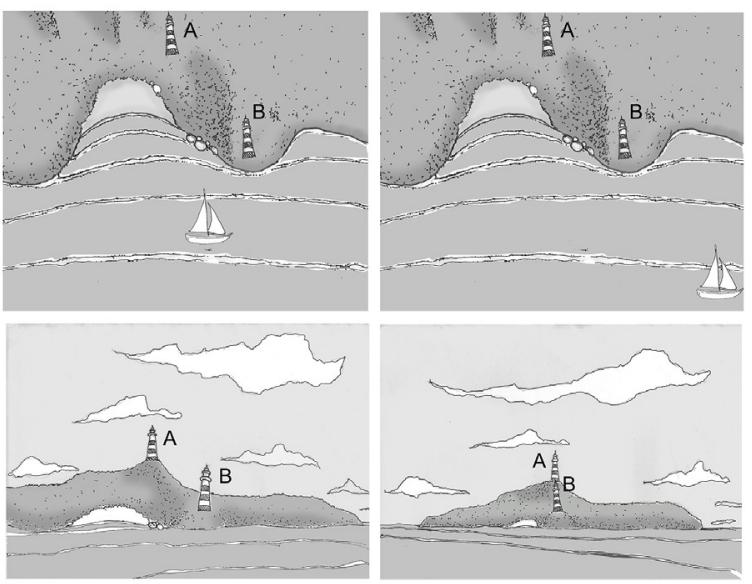

(ilustração: Bruno Aied Passos)

A navegação com o auxílio de mapas ou cartas baseia-se justamente na conciliação entre esses pontos de vista por meio do cotejo periódico das informações contidas no mapa com aquelas percebidas no ambiente e vice-versa. Trata-se de produzir correspondências ou equiparação entre imagens localizadas do ambiente e posições no mapa, o que, longe de ser trivial, requer familiaridade com o tipo de representação cartográfica, bem como o domínio de técnicas específicas e apuradas (Hutchins 1995; Pick Jr. et al. 1995; Ingold 2000:236).

Mas e a navegação sem o uso de mapas ou cartas, como é feita?

Há dois grandes modelos ou teorias concorrentes a este respeito. De um lado, aquele dos "mapas mentais" que, desde sua primeira formulação há quase 70 anos (Tolman 1948), tem recebido grande atenção e aceitação de psicólogos, historiadores, geógrafos e antropólogos. De outro, o que chamaremos de "abordagem ecológica", criada em deliberada oposição e como 
alternativa ao primeiro modelo. A despeito da diversidade e dos debates que cada um desses modelos abarca, é possível delinear e distingui-los a partir de seus pressupostos, conceitos e ênfases.

\section{Mapas mentais}

De acordo com o primeiro modelo, na ausência de um mapa ou carta artefatual, as pessoas valem-se de representações conhecidas por "mapas mentais" ou "mapas cognitivos" para se orientarem. Em poucas palavras, humanos em geral - e, para alguns autores, outros animais também - produziriam e memorizariam de forma organizada conhecimento relativamente rico sobre uma dada disposição espacial, contemplando a localização de si mesmos, dos demais objetos e suas correlações, a partir de experiências limitadas de apenas parte dessas relações. Gerados de experiências específicas com a disposição espacial particular em questão (Thorndyke \& Hayes-Roth 1982) e com outras disposições ao longo a vida, esses "mapas mentais" estariam por trás de nossa capacidade de fazer inferências nas localizações e distâncias sem experiência direta, bem como assumir mentalmente outro ponto de vista a respeito de uma dada paisagem, imaginando-se em uma posição diferente (Hintzman, Odell \& Arndt 1981).

Alfred Gell aponta que essas representações não devem ser entendidas de modo literal, como uma espécie de versão memorizada de um mapa artefatual, e tampouco são suficientes para garantir o sucesso da navegação. O autor propõe uma definição mais ampla de mapa, artefatual ou mental, como "qualquer sistema de conhecimento e/ou crença espacial que assume a forma de declarações não indexicais sobre as localizações espaciais de lugares e objetos" (Gell 1985:279), ou seja, cuja veracidade independe do contexto de sua enunciação, da posição e do movimento dos sujeitos - por exemplo, "Baía Formosa está ao norte de Baía da Traição". Tal conhecimento seria imprescindível a toda e qualquer navegação, conferindo ou não veracidade às proposições indexicais baseadas na posição do sujeito - "Baía Formosa está ao norte daqui". Seria somente em relação a coordenadas externas, independentes e objetivas que os sujeitos poderiam situar-se acertadamente no espaço, determinando sua localização atual e quanto a outros lugares. O mapa atenderia, assim, a uma "necessidade lógica" e "funcional", mais que psicológica. No mais, sua posse não garantiria o sucesso das decisões de navegação. Estas dependeriam da capacidade do navegador em estabelecer as devidas correspondências entre as imagens indexicais que ele produz localmente com as informações não indexicais de seu mapa artefatual ou mental. ${ }^{9}$ 
Enfim, para os teóricos do mapa mental em geral, toda e qualquer navegação, desde a mais simples e usual - como ir do quarto à cozinha na casa em que se reside - até a mais complexa - como longas travessias no mar ou deserto - envolveria sempre o emprego explícito ou subjacente de algum tipo de mapa, artefatual ou mental, bem como as mesmas operações cognitivas.

\section{A abordagem ecológica e o "descobrir-caminho"}

O outro modelo ou teoria a respeito da navegação sem mapas é aquele que chamaremos aqui de "ecológico", criado, como já dissemos, em contraposição e/ou como alternativa às teorias dos "mapas cognitivos". Segundo ele, a navegação mais fundamental e cotidiana prescinde de qualquer espécie de mapa, físico ou mental. Distingue-se assim, de maneira clara, a navegação sem mapa, denominada "descobrir-caminho" (wayfinding) por alguns autores. ${ }^{10} \mathrm{Nesta}$, o navegador depara-se não com um espaço físico exterior e absoluto cuja disposição dos componentes ele deve necessariamente representar em algum tipo de mapa, mas com um ambiente perceptual dinâmico que o envolve e se revela conforme ele se movimenta por "caminhos de observação". Cada caminho é especificado por uma sucessão particular de "vistas", isto é, configurações de aspectos ambientais visíveis e invisíveis. Ao percorrer tais caminhos, superfícies se revelam e se ocultam de maneira gradual, superpõe-se parcial ou completamente, entram e saem da vista em transições contínuas.

A navegação sem o auxílio de mapas consiste, portanto, em (re)produzir o fluxo de vistas e transições que se abrem adiante e se fecham atrás durante o caminho até o destino (Gibson 1986:197-198; Heft 1996:112; Ingold 2000:238-239). Tal qual uma estrutura narrativa ou musical, ela se baseia em informação organizada e fornecida ao longo do tempo, certa sucessão de vistas e transições, e não em conhecimento espacial sincrônico reunido em um mapa (Heft 1996:128-129; Ingold 2000:237-238). Aspectos do ambiente propícios à orientação e à locomoção são percebidos diretamente por meio de movimento exploratório, da passagem de um lugar a outro (e não indiretamente, por meio da reunião de imagens pontuais descontínuas em uma construção mental). Ao contrário do movimento intermitente na navegação com mapa, em que se alterna seguir adiante com paradas sucessivas para cotejamento das informações do mundo e do mapa, o deslocamento em "descobrir caminho" é contínuo, de modo a gerar o fluxo de vistas e transições particulares ao caminho (Heft 1996:122; Ingold 2000:239). 
Os lugares não correspondem, então, a pontos geométricos em um espaço abstrato, especificáveis por um sistema de coordenadas. No entanto, podem ser localizados com base em suas relações de sucessão e de inclusão em lugares mais amplos, como uma árvore em um bosque, um bosque em uma montanha, uma montanha em uma serra, ao longo de uma sequência de caminhos contíguos e interpostos (Gibson 1986:34, 68, 198; Heft 1996:119). Tal modelo destaca, portanto, a dimensão prática e ecológica da navegação, a interação concreta e localizada de navegador e ambiente, ao invés de alguma forma de ideação abstrata de um espaço absoluto.

Em suma, enquanto a teoria dos "mapas mentais" e a concepção ocidental dominante de navegação estão baseadas no que Harry Heft (1996:106) chama de "moldura metateórica cartesiana" sobre a percepção, a abordagem ecológica de "descobrir caminho" inspira-se na teoria alternativa da percepção formulada por James Gibson (1986). Em termos muito sucintos, a primeira reproduz a desconfiança dominante da tradição filosófica ocidental em relação ao papel da experiência perceptual para o conhecimento do mundo. A percepção é entendida como processo indireto de construção por inferência de uma representação mental (um mapa, por exemplo) a partir da internalização de estímulos físicos ambíguos e/ou insuficientes (um conjunto de perspectivas parciais localizadas, no caso) por órgãos receptores passivos. Distinguem-se, assim, os processos de sensação e cognição, bem como duas ordens de realidade: uma exterior, física e objetiva; outra interior, subjetiva e dotada de significados.

Por sua vez, segundo a teoria ecológica proposta por J. Gibson, a percepção é direta, dispensando operações mentais suplementares. Ela não se baseia na internalização de estímulos físicos por órgãos sensoriais passivos, mas em informação ecológica gerada pela ação exploratória do organismo no ambiente. O organismo percebe aquilo que o ambiente lhe propicia para a ação, suas propriedades funcionais, como o formato e a disposição de superfícies que podem ser apanhadas ou sobre as quais se pode andar (Gibson 1986:127). A atividade exploratória produz simultaneamente dois tipos de informação complementares. De um lado, informação sobre a "estrutura perspectiva", isto é, o fluxo de mudanças no "arranjo ótico ambiente", como a revelação e a ocultação de superfícies que se interpõem, as direções relativas delas, a ampliação do tamanho angular destas conforme nos aproximamos e a sua diminuição ao nos distanciarmos. ${ }^{11}$ De outro, informação sobre a "estrutura invariante", relacionada a aspectos que persistem ao longo do fluxo de transformações perspectivas, comuns a todos os pontos de observação e, portanto, compartilháveis, como relações de proporção de tamanho angular, padrões de mudança e de reversão (Gibson 1986:73- 
74, 209; Sedgwick 2001:140-141). A percepção concomitante de mudança e persistência especifica simultaneamente o ambiente ao redor do percebedor, bem como o percebedor no ambiente. Nem subjetiva nem objetiva, a percepção é sempre da relação organismo mais ambiente (Gibson 1986:126, 201; Reed 1988:288).

\section{Marcar a maré do peixe: quando ao invés de onde}

Em relação à náutica dos jangadeiros, não se trata aqui de decidir por uma ou outra teoria da navegação. Cabe por ora indagar se, para localizar os pesqueiros por meio da marcação por terra aqui descrita, os jangadeiros se valem necessariamente de alguma representação. E, em caso de resposta positiva, compreender qual o caráter desta representação: se ela fornece, de uma só vez, informação sobre todas as correlações espaciais entre jangadeiros, marcos terrestres e pesqueiros; e, neste sentido, se a metáfora cartográfica é, de fato, a mais adequada para designá-la.

Para gerar o caminho e o assento de um pesqueiro particular, o jangadeiro deve saber, entre outras coisas, quais pares de marcos terrestres observar, bem como as direções certas a seguir de modo a se alinhar com eles na sequência correta. Cada jangadeiro possui, então, seu próprio repertório de referências para chegar aos pesqueiros que conhece. Por conseguinte, dois pescadores podem utilizar marcações distintas para chegar a um mesmo pesqueiro, valendo-se dos alinhamentos de outros marcos terrestres, isto é, diferentes caminhos e assentos. Os jangadeiros memorizam e referem-se aos alinhamentos de marcos terrestres utilizados por meio de expressões como "farol na mata de cumaru", "poste na [árvore] mangueira de Joca", "coqueiro na caixa d'água da vila", "antena na ponta da barra". ${ }^{12}$ Tal conhecimento, uma relação de pesqueiros, caminhos e assentos, pares de marcos terrestres e rumos a seguir, é entendido por alguns autores como base para a produção de mapas mentais pelos pescadores (Maldonado 2000:84; Diegues 2000:04, 2001:391; Ramalho 2007:138-139). Devido ao "segredo" que envolve a localização de grande parte dos pesqueiros, não haveria um único mapa abarcando todos os pesqueiros. Cada pescador produziria seu próprio mapa, alguns mais ricos em informação do que outros, contemplando um maior número de marcações, conforme a experiência, a competência ou a "maestria" do navegador, como afirmam estes autores.

Cumpre notar, porém, quatro aspectos importantes da prática da marcação que a distanciam do sentido convencional de mapa pictórico: 
O primeiro é que o conhecimento pessoal de caminhos e assentos é organizado sob a forma de uma lista de proposições ordenadas hierarquicamente de modo que, para cada pesqueiro, tem-se:

$\{[($ marco terrestre $a+$ marco terrestre $b) \rightarrow$ caminho $C]+[($ marco terrestre $\mathrm{x}+$ marco terrestre $\mathrm{y}) \rightarrow$ assento $\mathrm{Z}]\} \rightarrow$ setor do pesqueiro $P$

Nesse sentido, este sistema até poderia ser pensado como uma espécie de "mapa mental" na acepção mais ampla proposta por Gell, como "sistema de declarações não indexais sobre localizações espaciais". Mas ainda assim, um "farol na mata de cumaru" é, mais do que uma coordenada que localiza o caminho, o índice do caminho em que se encontra a embarcação e que pode então ser percebido e percorrido, assim como um "coqueiro na caixa d'água da vila" é o índice do assento. Quando combinados, indicam quando e como se deve assentar a embarcação sobre o pesqueiro.

Segundo, diferente de um sistema de coordenadas que as fornece simultaneamente, cada alinhamento de marcos terrestres só é experimentado pelo navegador embarcado quando este se encontra conjuntamente disposto, tendo o marco terrestre mais próximo interposto entre ele e o marco mais distante. Por conseguinte, o navegador embarcado jamais vê todos os caminhos e assentos de uma só vez. Não há uma perspectiva supostamente totalizadora, pois, quando a embarcação se encontra em um caminho e/ ou assento particular, todos ou a grande maioria dos demais alinhamentos desaparecem para o navegador.

Terceiro, a ideia de que é unicamente a embarcação que se move em direção a um ponto estacionário de onde se podem ver os marcos terrestres imóveis e alinhados só faz sentido de uma perspectiva cartográfica. Para o navegador embarcado, não se trata tanto de ir até um alinhamento ou a um pesqueiro preexistente no espaço, mas de gerá-los em seu campo perceptual por meio do movimento relativo dos marcos terrestres ao longo de um "caminho de observação" no ambiente - ou seja, alinhamentos e pesqueiros não existem como elementos de um cenário estático, independentes de qualquer movimento.

Quarto e, neste mesmo sentido, a existência dos pesqueiros é condicionada à conjunção de ciclos diversos relacionados a períodos de reprodução e desova de diferentes espécies de peixes e crustáceos (a chamada "época da correição"), regimes de ventos, ritmo das marés, ciclo e trânsito lunares. Como nos explicou Oliveira, "não adianta só fazer a marcação por terra, tem que marcar a maré do peixe" (25/11/2015), saber em que momento do ciclo da maré os peixes "vêm comer" e podem ser encontrados. Na ocasião, retornávamos ao Tassi do Elias, pesqueiro que havíamos visitado cerca 
de 22 horas antes com Birino e Neco. Se da primeira vez a pescaria lá se limitara a poucos e pequenos piraúnas (Cephalopholis fulva), da segunda, surpreendeu a grande quantidade de ariocós (Lutjanus synagris), fisgados em pouco tempo. A diferença seria consequência da mudança para a lua cheia no segundo dia e entre os lançamentos das linhas de pesca no final e no início do movimento de maré vazante: pouco antes da baixamar, na primeira pescaria; e após a preamar, na segunda. ${ }^{13}$ De acordo com Oliveira, em geral, "bom é botar a linha no paramento da [maré] seca para a enchente. Porque no paramento da enchente para a seca, não adianta jogar linha, que não vai dar peixe" (19/10/2016). Para tanto, o movimento da maré e seus momentos de paramento são estimados conforme o trânsito da lua no céu, seus horários de nascimento e ocaso.

Algo semelhante foi descrito por John Cordell (1974) acerca do conhecimento mobilizado por pescadores de estuário e mangue em Valença, no sul da Bahia, ao decidirem diariamente quais pesqueiros visitar e que técnicas empregar. Baseado na percepção de relações causais entre os ciclos da lua e da maré, o comportamento dos peixes e a "ativação" dos pesqueiros, tal conhecimento organiza-se sob a forma de um calendário de maré lunar. Todavia, embora tenha antecipado a ideia do pesqueiro como um acontecimento, cuja existência está sujeita a tais ciclos (Cordell 1974:383), ainda assim se trataria, para o autor, de um "ponto de pesca" (fishing spot) a ser alcançado em momentos apropriados. Ora, como a técnica de marcação por terra mostra, pesqueiros são eventos ecológicos tanto de uma perspectiva (bio)física, causados por forças, circulação e conversão de matéria e energia em um mundo definível em termos de espaço e tempo, como de uma perspectiva perceptual, gerados pela circulação de informação em um ambiente de superfícies e meio móveis, especificado por mudanças e persistências (ver Bateson 1987 [1972]:467; Gibson 1986:100-102).

Para posicionar a embarcação e lançar linha no setor do pesqueiro, jangadeiros precisam considerar a direção da corrente e do vento, bem como o movimento da maré. A jangada não deve ficar exatamente sobre o pesqueiro, mas a alguns metros de distância deste, em direção à faixa de terra, na maré vazante, e em direção ao alto mar, na maré enchente. Desse modo, as linhas de pesca são levadas pela maré até a "cabeceira da pedra", onde os peixes maiores vêm se alimentar. Na medida em que as variações de correntes no mar e ventos arrastam a jangada, é preciso corrigir frequentemente sua posição. Seguindo o fundamento da marcação por terra, a saber, o movimento relativo (e constante) de marcos terrestres e jangada, a prática da marcação prossegue, mesmo enquanto se pesca, pois, ao chegar no setor do pesqueiro, o navegador deve fazer e manter um novo alinhamento, qual seja, aquele da 
embarcação com a pedra, de modo que os anzóis sejam levados pela maré e pelas correntes até a parte apropriada do pesqueiro. O que se busca não seria o "centro" das coordenadas do pesqueiro, mas o que há em volta deste, acompanhando o movimento dos peixes maiores que, por sua vez, acompanham os movimentos dos cardumes de peixes menores, que finalmente também estão sujeitos aos efeitos dos movimentos de marés e correntes.

Em suma, os pesqueiros não estão simplesmente lá como pontos em um espaço absoluto e mais amplo, aguardando serem (re)encontrados. Eles acontecem a partir da confluência, ou "correspondência" (Ingold 2013:107-108) de uma série de fatores ou "linhas de vida": o comportamento dos peixes, o ciclo das marés, as correntes de mar e de vento, enfim, o movimento relativo da embarcação e dos marcos terrestres no campo perceptual do navegador. Nesse sentido, as questões ou os problemas cruciais que a navegação por marcação por terra se propõe a resolver são mais quando e como ir ao pesqueiro do que onde ele está.

\section{Perceber o mundo em movimento}

Baseada no deslocamento relativo dos marcos terrestres, a marcação por terra requer movimento. É preciso deslocar a embarcação e, desse modo, os marcos terrestres correspondentes no campo perceptual do navegador (ver Figura 6b). É justamente a isso que se referem os jangadeiros quando afirmam que os marcos terrestres "correm", "giram", "andam", "sobem" e "enchem caminho". Mas como considerar tais afirmações? Estariam elas atreladas a uma representação particular do mundo? A percepção do ambiente em questão é ação embarcada, de quem "sai para a maré". Tais afirmações indicam posições relacionais de um observador em movimento, em uma paisagem em movimento, a partir de um sistema de referências concretas, que só podem ser acessadas por meio de operações de navegação, "na maré".

Se, de acordo com Hutchins (1995), todo sistema de navegação se volta em "nível computacional" para a resolução das mesmas questões fundamentais, suas diferenças dizem respeito sobretudo às representações e aos pressupostos empregados, refletindo sobre as operações realizadas e as soluções encontradas (ver nota 07). Para ilustrar esta tese, o autor fornece uma rica análise comparativa das náuticas ocidental moderna e micronésia. Desta, destacam-se duas noções-chave - os "caminhos de estrelas", também conhecidos como "constelações lineares", e as "ilhas de referência" etak utilizadas para definir a rota de uma ilha à outra e fornecer uma estimativa do trajeto percorrido. 
Cada "caminho de estrelas" corresponde a um conjunto de seis a dez estrelas que nascem uma após a outra em um mesmo ponto no horizonte a leste e se põem em outro ponto comum a oeste, descrevendo assim um mesmo trajeto no céu durante a noite. Os pontos nascentes e poentes de diferentes "caminhos de estrela" são utilizados pelos navegadores micronésios para definir direções no horizonte, formando uma espécie de "rosa dos rumos sideral". Trata-se de uma abstração que navegadores experientes são capazes de inferir por inteiro a partir da visão de apenas uma ou duas estrelas próximas à linha do horizonte.

Figura 8: [a] "caminhos de estrelas" e [b] "rosa dos rumos sideral" utilizada pelos nativos de Satawal, nas Ilhas Carolinas, definindo 32 direções a partir de 14 "caminhos de estrelas", com nascente (leste) em tan e poente (oeste) em tupul

[a]

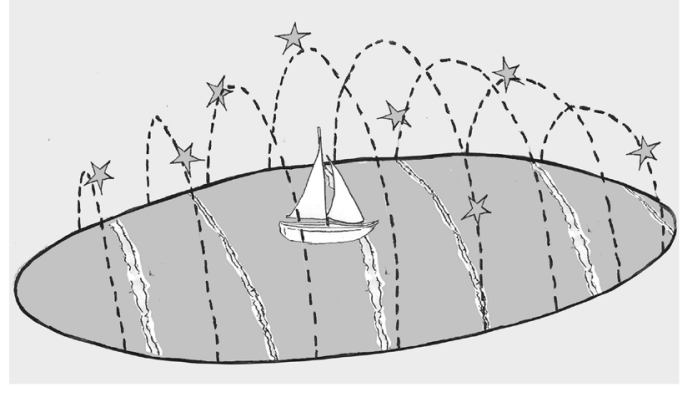

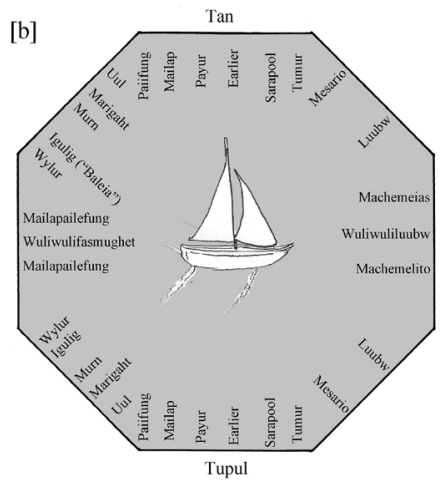

[b]

(ilustração: Bruno Aied Passos) $)^{14}$

A segunda noção central na náutica micronésia é a de etak, termo que designa uma terceira ilha utilizada como referência para a navegação entre duas outras ilhas. Trata-se de uma ilha, real ou imaginária, que se encontra além do horizonte, fora do campo de visão do navegador. Todo trajeto entre duas ilhas é pensado como a passagem da ilha de referência por uma determinada sequência de pontos da rosa dos rumos sideral no horizonte. À medida que a viagem progride, a ilha de referência muda sua orientação estelar em relação à embarcação. No início da viagem, quando a embarcação deixa a ilha de partida, o etak encontra-se sob um determinado ponto no horizonte. Conforme a embarcação avança em direção ao seu destino, o navegador imagina a ilha de referência movendo-se em sentido contrário, passando pelos demais pontos (Hutchins 1995:70-71, 83). O horizonte é imaginado como uma linha reta paralela ao curso da embarcação, e não como um círculo ao redor. As sequências de pontos no horizonte pelos quais a ilha de 
referência deve passar no trajeto de uma ilha à outra são memorizadas por meio de canções e narrativas. Os trajetos entre duas ilhas costumam ter mais que uma sequência de pontos, que são utilizadas conforme a época do ano, a direção e a intensidade de ventos e das correntes marinhas.

A navegação micronésia baseia-se, portanto, em um quadro de referência oposto àquele que fundamenta a náutica ocidental moderna. Os navegadores micronésios conceitualizam as viagens não como o deslocamento da embarcação sobre a superfície imóvel da Terra, mas em termos de uma embarcação estacionária e ilhas que se movem. A ilha de destino vem de encontro à embarcação, a ilha de partida afasta-se ficando para trás e, mais importante, a ilha de referência, o etak, segue em direção à embarcação pela linha paralela do horizonte, sob o pano de fundo fixo das direções estelares.

Figura 9: Perspectivas [a] aérea e [b] embarcada da navegação da ilha Woleai para Olimararo, com base em ilha de referência etak, caminhos de estrelas e rosa dos rumos sideral
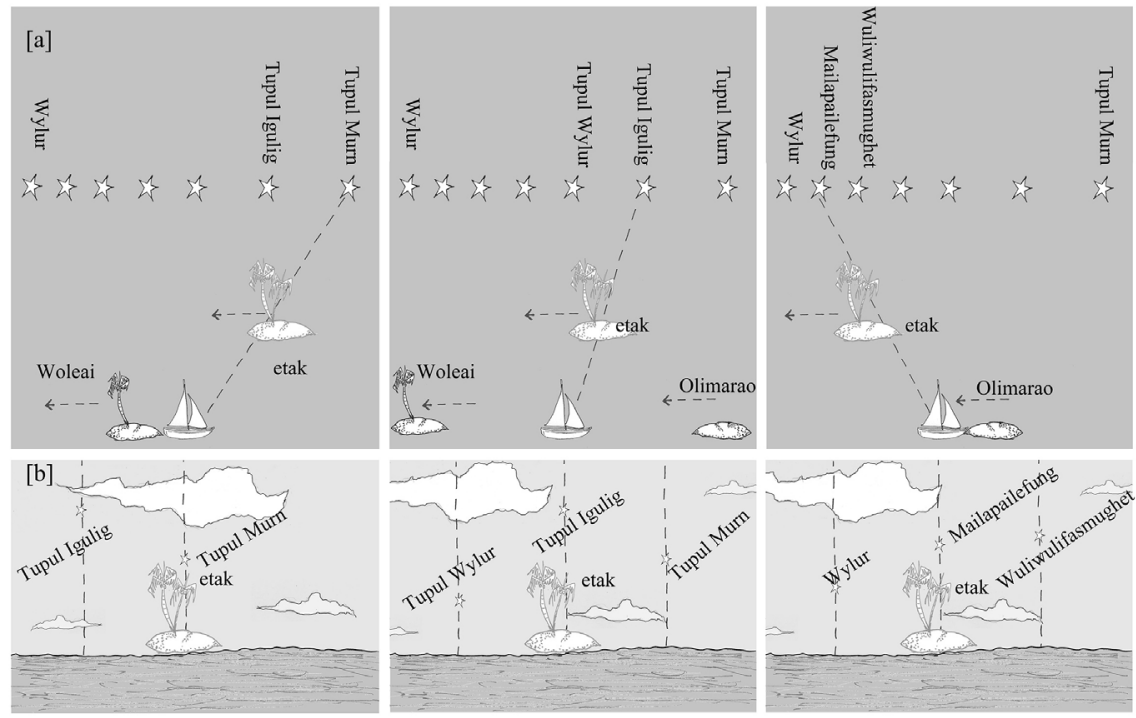

(ilustração: Bruno Aied Passos)

Segundo Hutchins, tal conceituação da viagem atende a necessidades funcionais. Na náutica ocidental moderna, atualizam-se as posições da embarcação e de um dispositivo de direções móvel (uma bússola ou giroscópio embarcados, cuja agulha gira livremente, voltando-se sempre para as direções norte e sul magnéticas) em relação a ilhas estacionárias. Por sua vez, para o navegador micronésio, é mais fácil atualizar as posições de ilhas móveis em relação a um quadro de referência fixo formado pela embarcação 
e o sistema direcional de pontos estelares no horizonte. Trata-se de representações coerentes com as informações produzidas e disponibilizadas aos navegadores em cada náutica. No caso micronésio, o navegador embarcado "visualiza" os movimentos na orientação estelar da ilha de referência etak além do horizonte (Figura 6b), no alinhamento de embarcação, ilha de referência e ponto estelar. Por conseguinte, da mesma maneira que o jangadeiro com as marcações que conhece, o navegador micronésio não pode ver de uma só vez todas as orientações estelares por que passa a ilha de referência. Diferente da moderna navegação ocidental, a náutica micronésia (Hutchins 1995:84-85) prescinde de uma perspectiva aérea, bem como da construção de um mapa, isto é, da representação sincrônica e totalizante de correlações espaciais entre localizações parciais.

Pois bem, o mesmo se dá com a marcação por terra praticada por jangadeiros, cujo quadro de referência utilizado é uma variante daquele empregado no sistema etak micronésio, ambos baseados na experiência perceptual do navegador embarcado. Ao "fazer a marcação", o jangadeiro volta a sua atenção menos para onde a embarcação se dirige e mais para os marcos terrestres que se movem ao redor. Ao se alinharem, a oclusão parcial do marco mais distante pelo marco mais próximo é utilizada para não só fornecer informação usual sobre a distância relativa e a ordem de profundidade dessas superfícies (Sedgwick 2001:134), mas também para produzir os alinhamentos de caminho e assento e, desse modo, um quadro direcional para a navegação. A principal diferença deste em relação àquele empregado no sistema etak micronésio diz respeito ao dispositivo direcional utilizado pelos jangadeiros, também externo à embarcação, porém, móvel. Na marcação por terra, os jangadeiros atualizam as posições de marcos terrestres e pontos de pesca móveis em relação à embarcação estacionária. 
Figura 10: Comparação entre os "quadros de referência" micronésio (sistema etak), de jangadeiros do nordeste brasileiro (marcação por terra) e da náutica ocidental moderna

\begin{tabular}{|c|c|c|c|}
\hline $\begin{array}{c}\text { quadro de } \\
\text { referência }\end{array}$ & $\begin{array}{c}\text { sistema etak } \\
\text { micronésio }\end{array}$ & $\begin{array}{c}\text { "marcação por terra" } \\
\text { de jangadeiros }\end{array}$ & $\begin{array}{c}\text { náutica ocidental } \\
\text { moderna }\end{array}$ \\
\hline perspectiva & $\begin{array}{c}\text { embarcada, parcial } \\
\text { e diacrônica }\end{array}$ & $\begin{array}{c}\text { embarcada, parcial } \\
\text { e diacrônica }\end{array}$ & $\begin{array}{c}\text { aérea, totalizante } \\
\text { e sincrônica }\end{array}$ \\
\hline embarcação & estacionária & estacionária & móvel \\
\hline mundo & móvel & móvel & estacionário \\
\hline sistema direcional & externo e fixo & externo e móvel & interno e móvel \\
\hline
\end{tabular}

É importante destacar, com Hutchins (1995:92), que tais quadros de referência, inclusive o ocidental moderno, respondem a exigências práticas de navegação, tornando algumas operações mais fáceis (e outras mais difíceis) de realizar conforme os recursos disponíveis. Suas formulações - por exemplo, a respeito de embarcações que permanecem estacionárias enquanto marcos terrestres ou ilhas se movem - são válidas, dignas de confiança e, portanto, adotadas apenas para a execução das tarefas específicas a que se destinam. Elas não dependem da crença de seus praticantes, nem correspondem a "visões de mundo" ou "cosmologias" absolutas que confeririam sentido a toda e qualquer experiência e ação daqueles que delas compartilham. Pelo contrário, seu valor é estritamente pragmático, assemelhando-se ao tipo de postura que adotamos ao nos valermos da posição e do movimento do sol no céu para estimar a hora do dia ou as direções cardeais sem, por isso, abrir mão de nosso entendimento heliocêntrico do mundo. ${ }^{15}$

\section{Conhecer em movimento}

Na bibliografia consultada a respeito da navegação e da pesca no nordeste brasileiro, a afirmação fundamental feita pelos jangadeiros de que os marcos terrestres se movem não teve a devida atenção. Como já dissemos, ao declarar que os marcos terrestres "correm", "giram", "andam" e "sobem", 
os jangadeiros se referem ao fenômeno de paralaxe de movimento relativo (Sedgwick 2001:143-144), a percepção de deslocamento do objeto observado conforme o movimento do observador. Tomar tais afirmações como representação, concepção exótica de mundo seria incorrer no que Ingold chama de "ilusão cartográfica" (2000:242), a ideia de que o mundo seria um palco pronto, imóvel e inanimado sobre o qual pessoas e embarcações, entre outros, se moveriam. Trata-se antes de uma constatação perceptual do navegador embarcado do que de uma representação, visão de mundo, formulação cosmológica ou enunciado filosófico. É algo que experimentamos com enorme frequência, bastando movermo-nos com os olhos abertos para tanto. Quando nos deslocamos - por exemplo, de nosso quarto de dormir à sala de estar - percebemos obstáculos e passagens ao longo do caminho sob a forma e por meio de superfícies que se revelam e ocultam, entram e saem gradativamente de vista. O conhecimento das relações no ambiente se realiza, então, na qualidade do movimento.

Trata-se de percepção no sentido ecológico proposto por James Gibson (1986), ou seja, a geração direta, por atividade exploratória, de informação propiciada pelo ambiente à ação. Desse modo, não faz sentido tratar a percepção do movimento dos marcos terrestres como ilusão, tampouco como realidade absoluta. Fenômeno ecológico por excelência, ele depende de certas propriedades relacionais de ambiente (como a disposição dos marcos terrestres e sua visibilidade conforme as condições atmosféricas) e navegador (sua visão e locomobilidade, por exemplo). O deslocamento angular dos marcos terrestres em direção ao seu alinhamento resulta da ação do navegador no ambiente, ao mesmo tempo em que orienta esta ação. À medida que a embarcação se desloca, o navegador percebe simultaneamente: o movimento dos marcos terrestres (o que J. Gibson chama de informação sobre a "estrutura perspectiva"); a persistência dos marcos na paisagem e, sobretudo, o caráter reversível desse movimento (informações sobre a "estrutura invariante").

Ao retornar ao local de partida, o navegador produz justamente a reversão do alinhamento e da oclusão parcial dos marcos terrestres, deslocando-os em sentido contrário. Tal reversibilidade é o que fundamenta e possibilita a navegação por marcação, pois, tão logo um novo pesqueiro é descoberto, faz-se a sua devida marcação por meio de processo inverso àquele descrito até aqui para retornar aos pesqueiros conhecidos. Ancorado sobre o pesqueiro recém-descoberto, o navegador seleciona dois marcos na costa que estejam alinhados, um mais alto que o outro. Em seguida, ele escolhe dois outros marcos alinhados da mesma maneira em outra direção na costa (ver Kottak 1966:218-219). 
Na marcação por terra, o fenômeno de percepção direta de "paralaxe de movimento relativo" constitui um "quadro de referência" em que a navegação é movimento com os marcos terrestres. Tal quadro de referência, como vimos, prescinde de uma perspectiva aérea, da representação sincrônica e totalizante de correlações espaciais entre localizações parciais, ao privilegiar a perspectiva embarcada dos pescadores e o movimento relativo dos marcos terrestres e demais elementos da paisagem. Essa ausência de totalização, articulada à reversibilidade dos alinhamentos no campo perceptual do navegador não só possibilita suas idas e vindas aos pesqueiros, como contribui para a manutenção do segredo sobre a localização destes. Uma vez que cada caminho e/ou assento só pode ser visualizado quando a embarcação se encontra devidamente alinhada com os marcos terrestres, é impossível para quem observa à distância inferir a localização de um pesqueiro. Articulam-se assim a técnica de navegação aqui analisada e um relevante aspecto sociológico da pesca na região, vastamente mencionado na literatura, relativo ao acesso aos recursos e à fonte de prestígio.

O segredo da marcação por terra é mais do que uma coordenada registrada na cabeça daqueles que são reconhecidos como mestres de navegação e pesca na região. Tal segredo é a habilidade de perceber e realizar certas qualidades de movimentos que permitem atualizar informações ecológicas das relações entre cardumes, pedras e dinâmicas ambientais na maré. A marcação por terra lida com um conhecimento distribuído na paisagem costeira, percebida em movimento - movimentos da jangada e dos marcos terrestres que "correm" na paisagem, mas também das correntes de mar, de astros, ventos e cardumes, a chamada maré do peixe.

Recebido em 27 de outubro de 2016

Aprovado em 28 de setembro de 2017

Gabriel Coutinho Barbosa e Rafael Devos são professores do Departamento de Antropologia, Programa de Pós-graduação em Antropologia Social da Universidade Federal de Santa Catarina, Florianópolis/SC, Brasil. E-mails: <ggabrielbar@gmail.com> e <rafaeldevos@yahoo.com> 


\section{Notas}

1 Tal investigação teve início em 2012. A partir de 2015, Rafael V. Devos juntou-se à mesma, aprofundando reflexões conjuntas realizadas no âmbito do Coletivo de Estudos em Ambientes, Percepções e Práticas - Canoa/CNPq (Devos, Barbosa \& Vedana, 2015). O presente artigo é uma versão estendida de apresentações realizadas no Grupo de Trabalho "Antropologia das populações costeiras", coordenado por Francisca de Souza Miller (UFRN) e José Colaço Dias Neto (UFF), durante o IV Reunião da REA/XIII Reunião da ABANNE, em agosto de 2013; no Fórum de Leituras "Antropologia, cartografia e afins", coordenado por Thiago Motta Cardoso, durante as Jornadas Antropológicas PPGAS/UFSC, em outubro do mesmo ano; nas "Quartas Indomáveis" do PPGAS/UFSCar, coordenadas por Felipe Vander Velden e Anna Catarina M. Vianna, em abril de 2014; nos Seminários do Núcleo de Fundamentos de Antropologia - AFunda/UFSC, coordenado por Miriam F. Hartung e Márnio Teixeira Pinto, em junho de 2014; e no Grupo de Trabalho "Antropologia da Técnica", coordenado por Carlos E. Sautchuk (UnB) e Fábio Mura (UFPB), durante a 29a Reunião Brasileira de Antropologia, em agosto de 2014. Agradecemos a todos e aos demais participantes pelas oportunidades e pelos comentários e, sobretudo, a José Antonio Kelly, Jeremy Deturche, Viviane Vedana, Brisa Catão Totti e Victor Vieira Paulo pela rica interlocução, sugestões e estímulo, bem como a Bruno Aied Passos pelas ilustrações.

2 Os municípios de Baía Formosa e Baía da Traição têm, cada qual, pouco mais de 8 mil habitantes (fonte: http://censo2010.ibge.gov.br/sinopse/index.php. Acesso em 23/10/2016). Em Baía da Traição há aproximadamente 65 embarcações pesqueiras motorizadas de pequeno e médio porte e 12 jangadas apenas (fonte: Colônia de Pescadores Z1 - Comandante Oscar Gonçalves, em Baía da Traição). Em Baía Formosa, são cerca de 70 embarcações pesqueiras motorizadas e 30 jangadas (fonte: Colônia de Pescadores Z11 - João Tomé da Silva, em Baía Formosa). Cumpre notar que ambos os municípios possuem pequenos portos com trânsito intenso de embarcações pesqueiras provenientes de diversos municípios da região. No mais, em 2016, foram registrados 346 e 239 pescadores artesanais, em Baía da Traição e Baía Formosa, respectivamente, conforme o Portal da Transparência do Governo Federal (http://www.portaltransparencia.gov.br/defeso/. Acesso em 23/10/2016).

3 Para uma classificação semelhante pelos pescadores de Tibau do Sul, no Rio Grande do Norte, ver Hélio Galvão (2006 [1968, 1969, 1989]:153-155). As diferenças entre as nomenclaturas fornecidas por Oliveira e Galvão podem refletir distinções no relevo do fundo do mar nessas duas regiões, sobretudo quanto ao grau de inclinação e o comprimento da plataforma continental.

4 Cumpre notar que a paisagem na região é marcada por longas praias contínuas e de mar aberto, separadas por falésias ou fozes de rios, havendo poucas baías protegidas. Há dunas e muitas falésias, além de enormes turbinas eólicas em alguns lugares. A cobertura vegetal é dominada por coqueirais, que se sobressaem às restingas, aos mangues e à mata atlântica. Uma linha descontínua de arrecifes de arenito acompanha a costa. Nos municípios de Baía da Traição e Baía Formosa, as construções são baixas com não mais do que dois ou três andares. 
5 Uma boa ilustração da paralaxe de movimento relativo e do alinhamento dos marcos terrestres em questão é fornecida pela experiência de olhar pela janela dentro de um trem ou ônibus em movimento. Os objetos que se encontram próximos ao trilho ou à estrada - postes de luz, por exemplo - são percebidos deslocando-se em sentido contrário àquele em que se está. Por sua vez, objetos situados mais longe, ao fundo - como árvores e montanhas - são percebidos deslocando-se de modo mais lento, no mesmo sentido para o qual se avança. Assim, conforme se segue adiante, os objetos mais próximos e aqueles ao fundo entrecruzam-se diante de nós, produzindo o alinhamento mencionado (ver Bateson 1986 [1979]:35).

6 O pescador leva a saçanga pela mão tocando o fundo do mar, medindo a profundidade e percebendo as sutis diferenças de composição no fundo do mar, tal qual um cego com sua bengala (ver Bateson 1987 [1972]:466). Utiliza-se também como saçanga um recipiente com sabão em pasta ou alguma outra matéria maleável, que adquira marcas ao tocar o fundo, indicando a composição deste. O uso da saçanga é imprescindível para a localização de pesqueiros mais distantes, sem terra à vista. Nesses casos, a navegação conjuga três práticas: a marcação de um caminho que mostra a direção, a manutenção dessa direção por meio de uma linha de corso acoplada à popa da embarcação quando o alinhamento de marcos terrestres não é mais visível e, por fim, a saçanga.

7 Hutchins baseia-se na distinção heurística entre níveis de análise e descrição de sistemas cognitivos proposta pelo neurocientista britânico David Marr (1982) a respeito da visão. Marr distingue três níveis principais para o entendimento de qualquer dispositivo que realize um processamento de informação: o computacional, relacionado às suas competências, isto é, aquilo que o sistema faz e por quê, os problemas que ele resolve e os processos executados para tanto (no caso da navegação, a definição de uma ou mais localidades e como ir de uma à outra); o representacional, que se refere às representações e aos "algoritmos" produzidos e utilizados na codificação e transformação da informação (na náutica ocidental moderna, unidades de distância e direção, fórmulas para conversões de informação analógica em digital e vice-versa, como coordenadas geográficas representadas ora por algarismos, ora por linhas em uma carta); e o físico, que remete à base física em que o processo é realizado (como cartas náuticas e uma porção particular do mar).

8 Cartas são ainda mais complexas e ricas em informação do que mapas, acrescentando à perspectiva destes um sistema de coordenadas geográficas que confere um endereço absoluto em termos de latitude e longitude às localizações na superfície terrestre, especificando posições, direções e distâncias relativas, permitindo ainda determinar os caminhos de uma posição a outra por meio de operações matemáticas e gráficas (Hutchins 1995:55-56).

9 A "teoria funcional da navegação" proposta por Gell (1985:280) baseia-se, portanto, em uma distinção entre: o território, que seria o "mundo real, composto de objetos e lugares em localizações espaciais, à luz do qual as crenças espaciais não indexicais são verdadeiras ou falsas"; o mapa do território, isto é, compêndios de crenças espaciais não indexicais; e a imagem do território, ou seja, crenças espaciais indexicais, baseadas na percepção dos objetos do território em relação a um sujeito percebedor. 
10 Ingold (2000:236-237) é radical a este respeito, empregando o termo "navegação" apenas à forma baseada no uso de mapa, restringindo-o, portanto, à sua moderna definição cartográfica. De nossa parte, mantemos o termo navegação em sua acepção mais ampla e original, do latim navigare, "conduzir uma embarcação", resultado da combinação de navis, "embarcação", com o verbo agere, "levar a cabo", de raiz lexical ag, "conduzir". É justamente isto que fazem os jangadeiros, a despeito de qualquer teoria empregada para compreender sua prática.

11 O "arranjo ótico ambiente" (ambient optic array) corresponde ao fluxo de luz onidirecional que preenche o meio e envolve o percebedor, como uma esfera fechada ao seu redor. Tal arranjo resulta das reflexões múltiplas e difusas da luz, com intensidades distintas, nas superfícies no ambiente e que chegam até a posição do observador. Os componentes desse arranjo não correspondem a cada objeto no espaço, já que alguns objetos encontram-se parcial ou completamente escondidos por trás de outros, mas a ângulos sólidos que têm o observador como vértice comum (Gibson 1986:66-68). Conforme o observador se move, o arranjo ótico muda, de modo que alguns de seus aspectos se conservam, enquanto outros se modificam.

12 Evidentemente, para preservar o segredo sobre as marcações, os alinhamentos apresentados no texto são fictícios.

13 A primeira visita, às $09 \mathrm{~h} 15$ do dia 24 de novembro de 2015, se deu pouco antes da primeira baixamar, enquanto a segunda visita, às $7 \mathrm{~h}$ do dia seguinte, ocorreu duas horas após a primeira preamar. Naquela madrugada houve enorme variação de amplitude entre as marés (mais de dois metros de diferença), provocada pela entrada da lua cheia no dia 25. Grandes coeficientes de marés como aquele costumam produzir intensa agitação de fundos do mar, alterando bastante as condições para a pesca entre uma maré e outra. Os dados de previsão de marés podem ser acessados em sites oficiais como o da Marinha do Brasil (http://www.mar.mil.br/dhn/chm/box-previsao-mare/tabuas/. Acesso em 18/10/2016), ou em sites especializados de pesca (http://www.tabuademares.com/br/paraiba/bahia-da-traicao. Acesso em 18/10/2016.)

14 Com base em Polynesian Voyaging Society. Disponível em: pvs.kcc.hawaii. edu/ike/hookele/star_compasses.html. Acesso em 21/10/2016).

15 Hutchins (1995:81-82) propõe um interessante experimento a este respeito, em que destaca a radical diferença entre, de um lado, a nossa experiência cotidiana, ordinária e intuitiva do movimento dos astros celestes no céu, de outro, nosso entendimento abstrato acerca da rotação da Terra sobre seu eixo e ao redor do sol. Para discussão semelhante sobre a percepção do chão plano que nos suporta e sobre o qual vivemos submetidos à força da gravidade e o entendimento da Terra como um esferoide sólido sobre cuja superfície se encontram distribuídas as coisas, ver Ingold (2011:99-114). 


\section{Referências bibliográficas}

ARAÚJO, Nearco B.G. de. 1990. Jangadas. Fortaleza: Banco do Nordeste do Brasil.

BATESON, Gregory. 1987 [1972]. Steps to an ecology of mind: collected essays in anthropology, psychiatry, evolution, and epistemology. Northvale (NJ, USA): Jason Aronson Inc. . 1986 [1979]. Mind and nature: a necessary unity. New York: E. P. Dutton.

CARDOSO, Thiago. 2014. "Malhas cartográficas: técnicas, conhecimento e cosmopolítica do ato de mapear territórios indígenas". Anais da ReACT - Reunião de Antropologia da Ciência e Tecnologia, 1(1):01-28. Disponível em: https://ocs.ige.unicamp.br/ojs/ react/article/view/1219. Acesso em 15/08/2015.

CASCUDO, Luís da Câmara. 2002 [1957]. Jangada: uma pesquisa etnográfica. São Paulo: Global.

CERTEAU, Michel de. 2001 [1990]. A invenção do cotidiano, vol. 1. Petrópolis (RJ): Editora Vozes

CORDELL, John. 1974. "The lunar-tide fishing cycle in Northeastern Brazil". Ethnology, 3(4):379-392.

DEVOS, Rafael V.; BARBOSA, Gabriel C. ; VEDANA, Viviane. 2015. "La formation du paysage : pratiques de pêcheurs au bord de la mer (Santa Catarina, Brésil)". Etudes Rurales, v. 196: 57-72. Disponível em: https:// www.cairn.info/revue-etudes-rurales-2015-2-page-57.htm. Acesso em 15/02/2016.

DIAS NETO, José C. 2012. "Segredos, pescadores e etnógrafos". Vivências: Revista de Antropologia, 40:121-129.

DIEGUES, Antonio Carlos (org.). 2000. A imagem das águas. São Paulo: Hucitec/ Nupaub.
2001. "Tradição marítima e oralidade: pesca de marcação e mestrança em Galinhos, Rio Grande do Norte - Brasil". Projeto História, 22:389-400. Disponível em: http:// revistas.pucsp.br/index.php/revph/ article/view/10749/7981. Acesso em 08/03/2016.

FORMAN, Shepard. 1970. The raft fishermen: tradition \& change in the Brazilian peasant economy. Imprenta Bloomington: Indiana University Press for International Affairs Center. GALVÃO, Hélio. 2006 [1968, 1969, 1989]. Cartas da Praia (reúne Novas Cartas da Praia e Derradeiras Cartas da Praia \& Outras Notas de Tibau do Sul). Natal: Scriptorin Candinha Bezerra/ Fundação Hélio Galvão.

GELL, Alfred. 1985. "How to read a map: remarks on the practical logic of navigation". Man, New Series, 20:2 (June 1985):271-286. Disponível em: https://www.jstor.org/ stable/2802385? seq=1\#page_scan tab_contents. Acesso em 15/01/2016. GIBSON, James J. 1986. The ecological approach to visual perception. New York: Psychology Press.

HEFT, Harry. 1996. "The ecological approach to navigation: a Gibsonian perspective". In: J. Portugali (org.), The construction of cognitive maps. Dordrecht (ND): Kluwer Academic Publishers. pp. 105-132.

HINTZMAN, Douglas L.; O'DELL, Carla \& ARNDT, David. 1981. "Orientation in cognitive maps". Cognitive Psychology, 13: 149-206. Disponível em: http://www.sciencedirect.com/science/article/pii/0010028581900074 Acesso em 18/02/2016.

HUTCHINS, Edwin. 1995. Cognition in the wild. Cambridge (EUA): MIT Press. 
INGOLD, Tim. 2000. The perception of the environment: essays on livelihood, dwelling and skill. London and New York: Routledge.

2011. Being alive: essays on movement, knowledge and description. London and New York: Routledge. 2013. Making: anthropology, archaeology, art and architecture. London and New York: Routledge.

KOTTAK, Conrad P. 1966. The structure of equality in a Brazilian fishing village. Ph.D. Dissertation, Columbia University Press.

MALDONADO, Simone C. 1993. Mestres \& mares, espaço e indivisão na pesca marítima. São Paulo: Annablume.

. 2000. "A caminho das pedras: percepção e utilização do espaço na pesca simples". Apresentação NUPAUB/ USP. Disponível em: http://nupaub. fflch.usp.br/sites/nupaub.fflch.usp. br/files/color/Microsoft\%20Word\%20-\%20A\%20Caminho\%20das\%20Pedras.pdf. Acesso em 18/02/2016.

MARR, David. 1982. Vision: a computational investigation into the human representation and processing of visual information. San Francisco: W.H. Freeman and Co.

OATLEY, Keith. 1977. "Inference, navigations and cognitive maps". In: P. N. Johnson-Laird \& P. C. Wason (orgs.), Thinking: readings in cognitive science. Cambridge: Univ. Press. pp. 537-547.
PICK JR., Herbert L. et al. 1995. "Topographic map reading". In: J. Flach; P. A. Hancock; J. K. Caird \& K. Vincente (orgs.), The ecology of human-machine systems. Vol. 2. Hillsdale, NJ/EUA: Erlbaum. pp. 255-284.

RAMALHO, Cristiano W.N. 2007. Embarcadiços do encantamento: trabalho como arte, estética e liberdade na pesca artesanal de Suape, PE. Tese de Doutorado, Universidade Estadual de Campinas - PPGAS/Unicamp.

REED, Edward S. 1988. James J. Gibson and the psychology of perception. New Haven and London: Yale University Press.

SEDGWICK, H.A. 2001. "Visual space perception". In: B. Goldstein (org.), Blackwell handbook of sensation and perception. Malden (EUA)/Oxford (Reino Unido): Blackwell Publ. pp. 128-167.

THORNDYKE, Perry \& HAYES-RO$\mathrm{TH}$, Barbara. 1982. "Differences in spatial knowledge acquired from maps and navigation". Cognitive Psychology, 14:560-589. Disponível em: https://msu.edu/course/psy/802/ snapshot.afs/altmann/802/Ch4-2-ThorndykeHayesRoth82.pdf. Acesso em 23/04/2016.

TOLMAN, Edward. 1948. "Cognitive maps in rats and men". Psychological Review, 55:189-208. Disponível em: http://psychclassics.yorku.ca/ Tolman/Maps/maps.htm. Acesso em 23/04/2016. 


\section{PARALAXE E “MARCAÇÃO POR TERRA": TÉCNICAS DE NAVEGAÇÃO ENTRE JANGADEIROS NA PARAÍBA E RIO GRANDE DO NORTE (BRASIL)}

\author{
MOTION PARALLAX AND FIXING \\ POSITION BY LANDMARKS: \\ NAVIGATION TECHNIQUES \\ AMONG RAFT FISHERMEN IN THE \\ NORTHEAST OF BRAZIL
}

\section{Resumo}

Descrevemos e analisamos aqui a técnica de marcação por terra, amplamente praticada por jangadeiros e demais pescadores na região Nordeste do Brasil para a localização de pesqueiros à luz do dia e mantendo a costa à vista. Baseada na perspectiva embarcada do jangadeiro e no movimento relativo de marcos terrestres no ambiente, tal técnica difere em vários aspectos de pressupostos e procedimentos da náutica ocidental moderna. Para tanto, valemo-nos dos debates entre o paradigma dos "mapas mentais" e a abordagem ecológica, destacando as contribuições da teoria funcional da navegação proposta por Alfred Gell, a teoria do "descobrir caminho" de James Gibson e Tim Ingold, entre outros, além da teoria computacional da navegação formulada por Edwin Hutchins.

Palavras-chave : N a veg a çã o, Jangadeiros, Percepção, Técnica, Pesca.

\begin{abstract}
This paper analyses a navigation technique widely practiced by raft fishermen in the Northeast of Brazil for locating fishing grounds in the light of the day and keeping the coast in sight. It consists of fixing position by lining up landmarks. Based on the embedded perspective of the fishermen and the motion parallax of landmarks in the environment, such a technique differs from modern Western navigating techniques in a number of ways. Engaging debates on the paradigm of "mental maps" and the ecological approach, we highlight the contributions of the functional theory of navigation by Alfred Gell, the theory of "wayfinding" by James Gibson and Tim Ingold, among others, in addition to the computational theory of navigation by Edwin Hutchins. Key words: Navigation, Raft fishermen, Perception, Technique, Fishing.
\end{abstract}


PARALAJE Y UBICACIÓN

DE POSICIÓN POR TIERRA:

TÉCNICAS DE NAVEGACIÓN

ENTRE PESCADORES BALSEROS

“JANGADEIROS” EN PARAÍBA Y RIO GRANDE DO NORTE (BRASIL)

\section{Resumen}

Describimos y analizamos la técnica de "marcación por tierra" utilizada por los "jangadeiros" (pescadores cuya embarcación es un tipo de balsa) y demás pescadores de la región del noreste del Brasil para la ubicación de locales de pesca durante el día y manteniendo la costa a la vista. Basada en la perspectiva embarcada del "jangadeiro" y del movimiento relativo de marcos terrestres en el ambiente, esta técnica se distingue en varios aspectos de los presupuestos y procedimientos de la náutica occidental moderna. Para la descripción y análisis, nos valemos de los debates entre el paradigma de "mapas mentales" y el abordaje ecológico, destacando, entre otros, las contribuciones de la teoría funcional de la navegación propuesta por Alfred Gell, la teoría de "descubrir caminos" de James Gibson y Tim Ingold, así como la teoría computacional de navegación formulada por Edwin Hutchins.

Palabras clave: Navegación, Pescadores balseros, Percepción, Técnica, Pesca. 